\title{
Galectins from the Nematode Caenorhabditis elegans and the Genome Project
}

\author{
線虫Caenorhabditis elegansのガレクチンとゲノムプロジェクト
}

\author{
Jun Hirabayashi*, Yoichiro Arata, and Ken-ichi Kasai \\ Department of Biological Chemistry, Faculty of Pharmaceutical Sciences, Teikyo University, Sagamiko, \\ Kanagawa 199-01, Japan, FAX: 81-426-85-3742, E-mail: XLA02445@ niftyserve.or.jp
}

Key Words: Caenorhabditis elegans, multiple genes, genome project, tandem-repeat type, molecular evolution

\section{Abstract}

The finding of Caenorhabditis elegans galectin (32 $\mathrm{kDa}$ ) demonstrated, for the first time, the presence of the "tandem-repeat type" of galectin, which consists of two homologous domains ( $c a .16 \mathrm{kDa}$ ). Its $\mathrm{N}$ - and $\mathrm{C}$-terminal half domains show relatively low sequence similarity to each other ( $c a$. $30 \%$ identity), though most (but not all) of the amino acids involved in the carbohydrate binding are conserved. The nematode 32$\mathrm{kDa}$ galectin shows strong hemagglutinating activity, but its saccharide specificity is rather complex. The individual half domains have considerably distinct features in the binding to asialofetuin-agarose. Though the endogenous ligand for them is not known, these observations imply that the $32-\mathrm{kDa}$ nematode galectin functions as a possible "heterobifunctional crosslinker". Since this galectin is localized most abundantly in the adult cuticle, it possibly plays a role in the formation of tight and insoluble epidermal layers. A recently isolated novel nematode galectin (16-kDa) forms a non-covalent dimer, and exhibits significant hemagglutinating activity, which is inhibitable by lactose. The current progress in the $C$. elegans genome project has revealed the presence of a number of galectin-related genes, and at least four other tandem-repeat-type galectins (40-75\% identical to the $32-\mathrm{kDa}$ galectin) have been proved to be expressed. Two closely related genes encoding CRDs (carbohydrate-recognition domains) having a somewhat longer C-terminal tail have also been predicted. Because the complete genome sequence of C. elegans ( $1 \times 108 \mathrm{bp})$ will be obtained in the near future, galectin research utilizing this model animal will hopefully provide us with new concepts about both the biological and evolutionary significance of multivalent galectin-carbohydrate interactions.

\section{要 約}

Caenorhabditis elegansで見つかったガレクチンは最初の直列 反復型ガレクチンとして記載される $32 \mathrm{kDa}$ の分子で、 $16 \mathrm{kDa}$ の

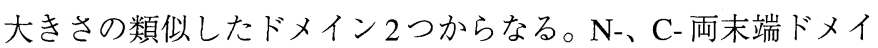
ンは糖結合に関わるアミノ酸残基のほとんど(すべてではない) を保存しているが、両ドメイン間の配列類似性は約 $30 \%$ と比較 的低い。この線虫 $32 \mathrm{kDa}$ ガレクチンは強い赤血球凝集活性を示 すが、糖に対する特異性は決して単純ではない。N-、C-両末端 ドメインをそれぞれ別個に発現させたとき、アシアロフェツイ ンーアガロースに対する結合力は両者で大きく異なっていた。こ れらのドメインに対するそれぞれの内在性リガンドはわかって いないが、これらの観察結果は、線虫 $32 \mathrm{kDa}$ ガレクチンが等価 でない二価性架橋分子として機能している可能性を示す。この ガレクチンは成虫クチクラ層に豊富に見出されることから、硬 くて不溶性の表皮層の形成に関わっているかもしれない。最近 単離された新しい線虫ガレクチン $(16 \mathrm{kDa})$ は非共有結合性の 2 量体を形成し、ラクトースで阻害される赤血球凝集活性を示す。 一方、C. elegansのゲノムプロジェクトの進展によって、これら 以外にも驚くほど多くのガレクチン関連遺伝子が見つかってい る。少なくともさらに 4 つの直列反復型ガレクチンが存在し (40〜75\%一致)、いずれも実際に発現されていることが確認され た。幾分長いC-末端をもった糖認識ドメイン (CRD) をコード する二つの類似遺伝子も見つかっている。C. elegansではゲ） 厶の完全構造 ( $\left.1 \times 10^{8} \mathrm{bp}\right)$ が近い将来解読されるという。この モデル生物を有効に使うことで、ガレクチンと糖鎖の相互作用 の生物的、進化的意義に関する新しい概念が誕生すると期待で きる。

\section{A. Three Architectural Types in the Galectin Family}

Previously, we proposed to classify galectins into three types based on protein architecture (Hirabayashi et al., 1992; Hirabayashi and Kasai, 1993); i. e., i) proto, ii) chimera, and iii) tandem-repeat types (Fig. 1). Though this classification does not assume their evolutionary relationship, it is strongly related

*To whom correspondence should be addressed.

\section{A. ガレクチン家系における3つの構築様式}

以前、我々は夕ンパク質の構築様式に基づいてガレクチン を3つの型に分類することを提唱した (Hirabayashi et al., 1992; Hirabayashi and Kasai, 1993 ; 図 1)。このプロト、キメラ、直列 反復型という分類方式はガレクチン相互の進化的な近縁関係を 示したものではないが、架橋分子としてのガレクチン機能の基 
Proto

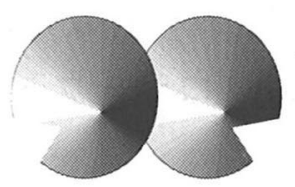

Two identical

Galectin CRDs

Can cross-link
homologous
carbohydrate
ligands
Chimera

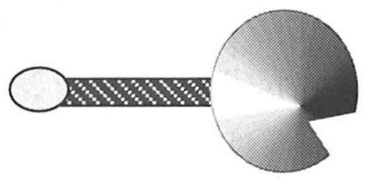

Gly,Pro,Tyr Galectin -rich repeated $\mathrm{CRD}$ Domain

Can cross-link carbohydrate and noncarbohydrate ligands

\section{Tandem-repeat}

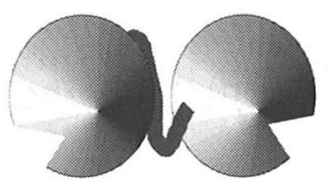

Two distinct Galectin CRDs

\author{
Can cross-link \\ two distinct \\ carbohydrate \\ ligands
}

Fig. 1. Three architectural types of the galectin family. Note that this classification (Hirabayashi et al., 1992) is simply based on protein architectural feature, and not based on similarities in protein primary sequence, saccharide specificity, or evolutionary kinship. However, this classification necessarily defines binding features of each type. Proto-type functions as homobifunctional cross-linker since usually this type forms a non-covalent dimer. Chimera-type can cross-link two distinct biomolecules, i.e., sugar and non-sugar ligand. The only chimera-type galectin actually investiated is galectin-3 in mammals, which also undergoes oligomerization under some conditions, and thus can act as an agglutinin. Tandem-repeat-type galectins can function as a heterobifunctional cross-linker (Arata et al., in press).

to their functions as a cross-linker (Kasai and Hirabayashi, 1996): the proto-type one usually forms a non-covalent homodimer, thus acting as a homobifunctional cross-linker. The other two types, chimera and tandem-repeat types can act as heterobifunctional cross-linkers. The basic difference between the latter two types is that the chimera type, consisting of galectin and non-galectin domains, may link carbohydrate and non-carbohydrate biomolecules (e.g., polynucleotide and polypeptide), whereas the tandem-repeat type can cross-link different types of glycoconjugates. Most of the past investigated galectins, including electric eel lectin (Paroutaud et al., 1987), two chicken isolectins (Ohyama et al., 1986; Hirabayashi et al., 1987; Sakakura et al., 1990), human placental lectin (galectin-1; Hirabayashi and Kasai, 1984; Gitt and Barondes, 1986; Hirabayashi and Kasai, 1988; Gitt and Barondes, 1991), belong to the proto type. More recently, new members of this type have also been found in various animal species; i.e., galectins- 2 (Gitt and Barondes, 1986; Gitt et al., 1992), -5 (Gitt et al., 1995a), and -7 (Magnald et al., 1995; Madson et al., 1995), human Charcot-Leyden crystal protein (Ackerman et al., 1993), frog galectins (Ahmed et al., 1996b), nematode 16-kDa galectin (Hirabayashi et al., 1996), and two sponge isolectins (Pfeifer et al., 1993). In contrast to the prototype galectins which have been found in a wide variety of animal species, a sole chimera type (i.e., galectin-3) has been found predominantly in mammals, but more recently also in the chicken (Nurminskaya and Lindsenmayer, 1996). The tandemrepeat-type is the latest oneto be recognized, and was found for the first time in the nematode Caenorhabditis elegans
本的な違いを表現している (Kasai and Hirabayashi, 1996)。プロ 卜型は非共有結合性の 2 量体を形成するので等価な架橋分子と 言えるが、キメラ型と直列反復型は非等価な架橋分子として機 能しうる。その違いは、キメラ型がガレクチンドメインと非ガ レクチンドメインからなるため、一方では糖鎖と、他方では糖 以外の生体分子(ポリヌクレオチドやポリペプチド)と架橋を形 成できるのに対し、直列反復型では異なるタイプの糖鎖を架橋 する点である。従来研究されてきたほとんどのガレクチンはプ ロト型である。これには代表的なものとして、電気ウナギレク チン (Paroutaud et al., 1987)、ニワトリの2つのレクチン (Ohyama et al., 1986; Hirabayashi and Kasai, 1987 ; Sakakura et al., 1990)、ヒト胎盤レクチン (ガレクチン -1; Hirabayashi and Kasai, 1984 ; Gitt and Barondes, 1986 ; Hirabayashi and Kasai, 1988 ; Gitt and Barondes, 1991) などが含まれる。より最近見つかったもの として、哺乳類では、ガレクチン -2 (Gitt and Barondes, 1986; Gitt et al., 1992)、ガレクチン -5 (Gitt et al., 1995a)、ガレクチン 7 (Magnald et al., 1995; Madson et al., 1995)、ヒト Charcot-Leyden 結晶タンパク質 (Ackerman et al., 1993)、また哺乳類以外で は、カエルガレクチン (Ahmed et al., 1996b)、線虫 $16 \mathrm{kDa}$ ガレ クチン (Hirabayashi et al., 1996)、海綿の2つのガレクチン (Pfeifer et al., 1993) を挙げることができる。このように多くの 生物種で見つかっているプロト型ガレクチンに対し、キメラ型 ガレクチン (唯一、ガレクチン -3がこれに相当) は哺乳類でし か見つかっていない (ごく最近、ニワトリからガレクチン -3 の 相同物が見つかった； Nurminskaya and Lindsenmayer, 1996)。直 列反復型は一番最後に見つかったが、我々が線虫 Caenorhabditis elegansで発見した $32 \mathrm{kDa}$ ガレクチンがその初めての例である 
(Hirabayashi et al., 1992). One possible reason why tandemrepeat-type galectins were not found earlier may be their basic insolubility, as has been demonstrated for porcine galectin- 4 . This protein is involved in cell-to-cell attachment as a possible junction protein and is extractable only with $9 \mathrm{M}$ urea (Chiu et al., 1994). This insolubility can be related to their potential as a heterobifunctional cross-linker (Arata et al., in press; Brewer, in this issue).

\section{B. C. elegans 32-kDa Galectin: Structure, Function and Localization}

The first galectin found in C. elegans is a $32-\mathrm{kDa}$ protein, which consists of two homologous lectin domains of approximately $16 \mathrm{kDa}$. Both domains show approximately $25 \%$ amino acid sequence identities to vertebrate galectin carbohydrate-recognition domains (CRDs). Since the homology between the two repeated domains (30\% identity) is still higher than this value, they appear to have diverged by gene duplication from an ancestral galectin domain significantly later than the divergence between nematodes and vertebrates (Hirabayashi et al., 1992). The nematode 32-kDa galectin is not necessarily a counterpart molecule of any of the mammalian tandem-repeat-type galectins; i.e., galectins-4 (Oda et al., 1993), -6 (Gitt et al., 1995b), -8 (Hadari et al., 1995) and -9 (Sahin et al., 1995). Notably, both this and another galectin (16-kDa proto-type galectin, described below) were purified by the same strategy as has been used for vertebrate galectins, i.e., with specific extraction with lactose, followed by asialofetuin-agarose affinity chromatography. The success of this strategy suggests that these nematode galectins retain the basic sugar-binding properties found in vertebrate galectins.

Study of the structure and function of the $32-\mathrm{kDa}$ nematode galectin will giveus an answer to the very fundamental question as to whether its two CRDs exhibit similar or distinct sugar-binding properties. We prepared recombinant genes for expression in E. coli of individual N- and C-terminal half domains $(16 \mathrm{kDa})$, together with native $32-\mathrm{kDa}$ galectin by using the pET/T7 RNA polymerase system (Arata et al., in press). It should be noted that the conserved hexapeptide sequence, "His-Phe-Asn-Pro-Arg-Phe" responsible for the recognition of galactose 4-OH group (Lobsanov et al., 1993, Liao et al., 1994; Bourne, et al., 1994) is maintained in the Cterminal half domain, but is substituted by "His-Val-Ser-ValArg-Phe" in the N-terminal domain. When their sugar-binding affinities were assessed by means of frontal affinity chromatography (Kasai et al., 1986), the C-terminal domain showed only one-seventh of the binding strength of native $32-\mathrm{kDa}$ galectin to asialofetuin, probably due to the loss of multivalency. On the other hand, the $\mathrm{N}$-terminal domain showed significant, but much lower, affinity to this glycoprotein. Gel filtration analysis showed that both $\mathrm{N}$ - and $\mathrm{C}$-termi-
(Hirabayashi et al., 1992)。直列反復型が比較的最近まで見つから なかった一つの理由として、不溶性の問題が考えられる。例え ば、このタイプに属するブタガレクチン -4 はジャンクションタ ンパク質の一つとして細胞間接着の機能が推定されているが、9 $\mathrm{M}$ 尿素を用いなければ抽出できないという (Chiu et al., 1994)。 この点は直列反復型のガレクチンが非等価な架橋分子として機 能しうるという上述の性質と関係があるかもしれない (Arata et al., in press ; Brewer, in this issue)。

B. C. elegans 32-kDa ガレクチン：構造、機能、および局在

C. elegansで最初に見つかったガレクチンは、約 $16 \mathrm{kDa}$ の 類似したガレクチンドメインが 2 回繰り返した $32 \mathrm{kDa}$ のタンパ ク質であった。両ドメインは脊椎動物でわかっていた各ガレク チンの糖認識ドメイン (CRD) と約 $25 \%$ のアミ酸配列上の一 致を示す。この值は繰り返しドメイン間の類似性 (30\%の一致) より若干ではあるが有意に低いため、反復ドメイン部分の遺伝 子重複は、脊椎動物と線虫が共通の祖先から分岐した後で起こっ たものと考えられる (Hirabayashi et al., 1992)。しばしば誤解さ れることだが、線虫32-kDa ガレクチンは必ずしも哺乳類で見つ かっている類似構造のガレクチン [ガレクチン -4 (Oda et al., 1993)、-6 (Gitt et al., 1995b) 、-8、 (Hadari et al., 1995) -9 (Sahin et al., 1995)] の完全な相同物ではない。 $32 \mathrm{kDa}$ ガレクチンも、後 に見つかった $16 \mathrm{kDa}$ ガレクチン (後述) も、脊椎動物ガレクチ ンの精製法と同じ操作で単離できる点には注目すべきである。両 者で用いられるのは、ラクトースによる特異的抽出とアシアロ フェツイン - アガロースによるアフィニティークロマトグラ フィーである。このことは、これら線虫ガレクチンが脊椎動物 ガレクチンと基本的に同じ糖結合性を保持していることを示唆 する。

線虫 32-kDa ガレクチンの構造 - 機能相関に関する研究は、 大変基本的な問題を含んでいる。このガレクチン分子が持つ2つ の糖認識ドメインが、果たして同じ糖結合特異性を示すものな のか、あるいは異なった性質を示すものなのかを調べるため、 我々は32-kDaガレクチンそのものに加え、N-末端側、およびC末端側のドメインを単独で発現すべく、組み換え遺伝子を調製 した。発現系には pET/T7 RNA ポリメラーゼによる大腸菌発現 系を用いた (Arata et al., in press)。ここで、N-末端側ドメイン ではガラクトースの 4位水酸基の認識に関わる保存されたへキ サペプチド、“His-Phe-Asn-Pro-Arg-Phe” (Lobsanov et al., 1993, Liao et al., 1994 ; Bourne, et al., 1994) が “His-Val-Ser-Val-Arg-Phe" に置き換わっている点は言及しておく必要がある(下線部は置換 アミノ酸)。前端アフィニティークロマトグラフィー(Kasai et al., 1986) という分析法で調べたところ、単独発現したC-末端側の ドメインでは、32-kDaガレクチンと比較してアシアロフェツイ ンに対する結合力が 7 分の 1 に低下していた。これは扔そらく 単独発現によって多価でなくなったためと考えられるが、N-末 
nal half domains were eluted at the retention time for a monomer $(16 \mathrm{kDa})$. Neither of them showed significant hemagglutinating activity, whereas the native galectin showed strong hemagglutinating activity. Considering the fact that both $\mathrm{N}$ - and $\mathrm{C}$-terminal domains retain similar extents of sequence homology to other galectins ( $c a .25 \%$ ) and that native $32-\mathrm{kDa}$ galectin has strong hemagglutinating activity, the $\mathrm{N}$-terminal domain may have binding activity toward an as yet unidentified oligosaccharide(s). Since $\mathrm{N}$-acetylgalactosamine is more abundant than unmodified galactose in C. elegans (Furukawa, K., personal communication; Bakker, H., personal communication), di- $N$-acetyllactosamine is a possible candidate as a receptor saccharide.

By immunohistochemical study, the 32-kDa nematode galectin was most prominently localized in cuticle of the adult worm. On the other hand, egg and worms of each developmental stage were only weakly stained (Arata et al., 1996). The main component of the adult cuticle is collagen (Wood, 1988). Therefore, it is possible that the $32-\mathrm{kDa}$ galectin is involved in the formation of tough and insoluble adult cuticle as a result of cross-linking. This galectin is also found, in the terminal bulb of the pharynx where food is physically processed before being pumped into the gut. Thus, the $32-\mathrm{kDa}$ nematode galectin shares common properties with vertebrate galectins with respect to multiple locations feature (see Colnot et al., in this issue).

For some unknown reason, no cosmid clones encoding the 32-kDa galectin have been registered as a result of the $C$. elegans genome project. This suggests that a few cosmid clones are still missing. Therefore, we adopted the conventional strategy for genomic cloning. C. elegans genome DNA was digested with relevant restriction enzymes, and target gene fragments were cloned into plasmid pBluescript by means of colony hybridization. By combination with genomic polymerase-chain reaction (PCR) and subsequent dideoxy-termination sequencing, the entire region of 32-kDa galectin spanning over $5 \mathrm{kbp}$, including start and termination signals for the coding region as well as the poly(A) signal, was completely sequenced (Arata et al., in preparation). The absence of signal sequence for secretion was also confirmed. The presence of two introns consisting of 2,430 bp (intron 1) and $631 \mathrm{bp}$ (intron 2) was revealed. The first intron is relatively long in comparison with othor introns found in C. elegans, and inserted after the ninth codon from the initial methionine codon. This insertion position closely corresponds to the intron-insertion position previously identified for mammalian galectin-1 (Gitt et al., 1990), -2 (Gitt et al., 1992), -3 (Gritzmacher et al., 1992) and chick 14-kDa galectin genes (Ohyama and Kasai, 1988). On the other hand, the second intron was inserted at a position where no intron has been observed in the vertebrate galectins. Apparently, further consideration is necessary to elucidate reasons for
端側のドメインでは、さらに大幅な結合力の低下が認められた。 ゲル滤過によりオリゴマー構造を調べたところ、N-末端側、C末端側ドメインいずれの場合も単量体 $(16 \mathrm{kDa})$ として溶出され ることがわかった。また、両者はいずれも有意の赤血球凝集活 性を示さなかった。しかし、N-、C-両ドメインが他のガレクチ ンと同程度のアミノ酸配列類似性(約 $25 \%$ ) を示すこと、32- kDa ガレクチンが強い赤血球凝集活性を示すことを考えると、N-末 端ドメインは $N$-アセチルラクトサミンとは異なる構造未知のオ リゴ糖に強く結合するのかもしれない。C. elegansでは未修飾の ガラクトースよりもN-アセチルガラクトサミンの方が多量に検 出されており (Furukawa, K., personal communication; Bakker, H., personal communication)、ジ-N-アセチルラクトサミンが $\mathrm{N}$-末端 ドメインの相手糖鎖である可能性もある。

免疫組織化学的な研究によると、32-kDa 線虫ガレクチンは 成虫の表皮に最も多く見いだされるが、卵や各発生段階の幼虫 にはわずかしか認められない (Arata et al., 1996)。成虫表皮の主 成分はコラーゲンとされている (Wood, 1988)。それ故、32-kDa ガレクチンは等価でない架橋を作って、強固で不溶性の成虫表 皮の形成に関わっているのかもしれない。このガレクチンは、一 方ではpharynx (咽頭) と呼ばれる、食物を物理的に破砕し胃へ 送り込む器官にもかなり局在している。このように多様な局在 性は脊椎動物由来のガレクチンにも認められる共通した性質で ある (Colnot et al., this issue)。

理由は定かではないが、32-kDaガレクチンをコードするコ スミドクローンがC. elegansゲノムプロジェクトでは得られてい ない。抒そらく、プロジェクトでもいくつかのコスミドクロー ンについては、まだ完全にカバーしていないのだろう。したがっ て我々は、線虫独特の方法ではなく、より一般的な方法で遺伝 子クローニングを行うことにした。C. elegansのゲノム DNAを 適当な制限酵素で消化し、目的の遺伝子断片のサイズのDNAを プラスミド pBluescript へ挿入後、 $0.8 \mathrm{kbp}$ のcDNAをプローブと しコロニーハイブリダイゼーションを行った。さらにゲノム DNAを用いたポリメラーゼ・チェーン・リアクション (PCR) と 引き続くジデオキシターミネーション法によって、翻訳開始、停 止コドン、ポリ (A) シグナル等を含む32-kDa ガレクチン遺伝子 全領域 (約 $5 \mathrm{kbp}$ ) の塩基配列を決定した (Arata et al., in preparation)。本レクチン遺伝子にはシグナル配列に相当するも のがないことも確認された。一方、イントロンは2箇所見つかっ た (イントロン -1、イントロン -2)。イントロン-1 (2,430bp) は 線虫の遺伝子に見られるものとしては比較的長いもので、開始 メチオニンのコドンから 9 番目の位置に挿入されていた。この 位置は今まで明らかにされている哺乳類のガレクチン-1 (Gitt et al., 1990)、-2 (Gitt et al., 1992)、-3 (Gritzmacher et al., 1992)、お よびニワトリの $14 \mathrm{kDa}$ ガレクチン (Ohyama and Kasai, 1988)の 遺伝子におけるイントロン挿入位置にほほ対応している。これ に対し、イントロン -2 (631 bp) はこれまでの脊椎動物ガレクチ ン遺伝子では全く見られない位置に挿入されていた。このよう な保存性、および非保存性のイントロン挿入位置の理由につい 
such conserved and non-conserved exon/intron organization.

\section{C. elegans 16-kDa Galectin: A Proto-type Dimeric Galectin}

The second $C$. elegans galectin had originally been believed to be a degradation product of the above $32-\mathrm{kDa}$ galectin. In fact, the $16-\mathrm{kDa}$ protein is obtained as a minor component relative to the $32-\mathrm{kDa}$ galectin where the conventional extraction procedure is employed. In addition, the tandem-repeat structure of the $32-\mathrm{kDa}$ galectin seemed to be susceptible to endogenous proteases, resulting in the generation of $16-\mathrm{kDa}$ fragment(s) (Oda et al., 1993; Tardy et al., 1995). However, this possibility turned out not to be the case. We improved the cultivation conditions to obtain as much starting material as possible and also changed the extraction conditions, using buffer containing $\mathrm{Ca}^{2+}$ in place of phosphate buffer containing $\beta$-mercaptoethanol and EDTA. These changes resulted in great improvement in the yield of $16-\mathrm{kDa}$ lectin.

On the basis of peptide sequencing of the thus purified 16-kDa protein and subsequent reverse-transcriptase polymerase-chain reaction (RT-PCR), a full-length cDNA was cloned. As a result, the 16-kDa lectin proved to be a proto-type, novel member of the nematode galectin family; the protein consists of 146 amino acids and exists as a non-covalent dimer (Hirabayashi et al., 1996). A recombinant 16-kDa galectin was produced in Schizosaccharomyces pombe in a novel ASPEX expression system (Giga-Hama et al., 1994), which yielded 50 $\mathrm{mg}$ of purified 16-kDa galectin in a soluble form from a oneliter culture (Hirabayashi et al., unpublished result). By using this recombinant protein, we determined the binding specificity for simple saccharides by means of the hemagglutination-inhibition assay. Various $\beta$-galactosides were found to be effective in the following order of affinity: (LacNAc)2, lacto-N-tetraose $>\mathrm{N}$-acetyllactosamine $>$ thiodigalactoside, 2'-Fuc-lactose $>$ lactose. On the other hand, galactose-containing saccharides, such as Galß1-6GlcNAc, 3-Fuc-lactose, melibiose, Gal, GalNAc, Me- $\beta-$ Gal, Me- $\alpha-$ Gal were not inhibitory toward the hemagglutination, nor were glucose, mannose, $\alpha$-Me-Man, LFuc, and sucrose. Such a feature is closely similar to that observed for vertebrate galectins. This result is reasonable because the $16-\mathrm{kDa}$ galectin conserves all of the critical amino acids (Hirabayashi and Kasai, 1991; 1994) involved in the binding of galectin-2 (Lobsanov et al., 1993) and -1(Liao et al., 1994) to lactose/ $\mathrm{N}$-acetyllactosamine, respectively.

An attempt to identify the endogenous ligand for the 16$\mathrm{kDa}$ galectin was made by use of $16-\mathrm{kDa}$ galectin-immobilized agarose. In this case, we used a fusion protein with E. coli bgalactosidase $\alpha$-peptide (designated recN16 $\alpha$ ) expecting that the $\mathrm{N}$-terminal a-region would work as a flexible linker (16$\mathrm{kDa}$ galectin has only one lysine residue available for coupling to $\mathrm{CNBr}$-activated agarose, whereas the a-peptide moiety has
ては、今後さらに考察を加える必要があろう。

C. C. elegans $16 \mathrm{kDa}$ ガレクチン: プロト型二量体ガレクチン C. elegans 第二のガレクチン $(16 \mathrm{kDa})$ は、当初 $32 \mathrm{kDa}$ ガ レクチンの分解産物と考えられていた。実際、この $16 \mathrm{kDa}$ タン パク質は、今までと同様の精製法を用いている限り、32 kDa ガ レクチンに比べて少量成分としてしか得られない。加えて、32 $\mathrm{kDa}$ ガレクチンの (直列反復という) 構造は内在性プロテアーゼ による切断を受けやすいとも考えられた(消化により半分の分子 量 $16 \mathrm{kDa}$ の断片が生じる) (Oda et al., 1993 ; Tardy et al., 1995)。 しかし、事実はこれと違っていた。問題解決には、ある程度の 量の $16 \mathrm{kDa}$ タンパク質が必要であったが、我々は第一に虫の飼 育方法を改良し、多くの虫を簡便に調製できるようにした。第 二に、抽出法を検討し、従来の $\beta$-メルカプトエタノールと EDTAを含むリン酸緩衝液を抽出緩衝液として用いる代わりに、 カルシウムを含むトリス緩衝液を用いることで、 $16 \mathrm{kDa}$ レクチ ンを効率よく調製することができた (Hirabayashi et al., 1996)。

こうして得た $16 \mathrm{kDa}$ ガレクチンの詳細なぺプチド解析、お よびRT- PCR 解析に基づき、全長 cDNAクローンを得た。その 結果、 $16 \mathrm{kDa}$ レクチンはプロト型に属する新しい線虫ガレクチ ンのメンバーであることが判明した(Hirabayashi et al., 1996)。こ のガレクチンは146アミノ酸からなり、非共有結合性の二量体 として存在する。我々は組み換え $16 \mathrm{kDa}$ ガレクチンを分裂酵母 Schizosaccharomyces pombeを宿主とする新しい発現系 (ASPEX : Giga-Hama et al., 1994) によって調製した。この発現 系を用いることで、1リットル培養液あたり $50 \mathrm{mg}$ もの組み換 え $16 \mathrm{kDa}$ ガレクチンを可溶性の状態で精製できた (Hirabayashi et al., unpublished result)。得られた組み換えタンパク質を用いて、 簡単な糖に対する結合特異性を赤血球凝集阻害によって調べた ところ、N-アセチルラクトサミン二量体 (LacNAc) 2、ラクト N-テトラオース > N-アセチルラクトサミン > チオジガラクト シド、2'-フコシルラクトース>ラクトース、の順で強い阻害活 性が認められた。一方、ガラクトース含有糖であっても Galß16GlcNAc、3-フコシルラクトース、メリビオース、Gal、GalNAc、 Me- $\beta$-Gal、Me- $\alpha$-Gal には阻害効果が認められなかった(グル コース、マンノース、 $\alpha$-Me-Man、L-Fuc、シュクロースも同様)。 このような傾向は脊椎動物ガレクチンにも共通するものである。 この点はガレクチン -1 や-2が、N-アセチルラクトサミン (Liao et al., 1994)、およびラクトース (Lobsanov et al., 1993) と結合す る際に直接関与している重要なアミノ酸 (Hirabayashi and Kasai, 1991；1994）を、16 kDaガレクチンがすべて保存していること を考えると納得できる。

$16 \mathrm{kDa}$ ガレクチンの内在性リガンドを同定しようとする試 みは、このレクチンを固定化したアガロースを用いて行われた。 ただしこの目的には、 $16 \mathrm{kDa}$ ガレクチンそのものではなく、大 腸菌 $\beta$ ガラクトシダーゼ $\alpha$ ペプチドとの融合タンパク質 (recN16 $\alpha$ と略) が用いられた。その理由は、ガレクチン部分に はブロムシアン活性化ゲルへの固定化に使えるアミノ基が $1 つ$ しかないのに対し、 $\alpha$ ペプチド部分には 3 つのアミノ基がある 
three amino groups). A number of glycoproteins were adsorbed, most typically, 300 and $150 \mathrm{kDa}$ glycoproteins. All of them gave a positive signal upon lectin-probing by Westernblotting analysis (Hirabayashi et al., 1996). It should be noted, however, that lactose did not effectively inhibit this lectin blotting, whereas the binding to laminin was completely inhibited with the same concentration of lactose. Therefore, saccharide chains in these endogenous ligands for the nematode $16-\mathrm{kDa}$ galectin seem to be significantly different from those of vertebrate glycoconjugates.

\section{Other C. elegans Galectins Predicted by the Genome Project}

The C. elegans genome project (Coulson et al., 1988) is now been in progress for complete determination of the whole nucleotide sequence of the $C$. elegans genome (approximately $10^{8} \mathrm{bp}$ ). Beginning with chromosome III (C. elegans genome consists of five autosomes I-V and one sex chromosome $\mathrm{X}$ ), up to the present, almost $60 \%$ of the entire sequence has been analyzed. In the course of the project, it became evident that there are a significant number of other galectin genes (originally based on personal communication with D.N.W. Cooper; Table I). Prediction of each gene function is systematically made by use of established searching programs: i) Genefinder (P. Green and L. Hillier, unpublished), to search for possible open reading frames and most probable exon/intron splicing regions, ii) Blast programs for homology search based on thus predicted amino acid sequences (Altschul et al., 1990). These data are also included in the GeneBank/EMBL/DDBJ DNA databases.

To the present, six new galectin-related genes have been identified. Four of them encode tandem-repeat-type galectins (tentatively designated here as Cel-II, III, IV and V, whereas Cel-I is the $32-\mathrm{kDa}$ galectin). Their deduced amino acid sequences are $40-75 \%$ identical to the $32-\mathrm{kDa}$ galectin (Cel-I).
からである。この部分を介して優先的に固定化させることで、柔 軟なリンカーとしての機能も期待できる。事実、多くの糖夕ン パクがこのカラムに吸着したが、中でも分子量 $300 \mathrm{kDa}$ と 150 $\mathrm{kDa}$ のタンパク質が含量も高く注目された。これらはすべてレ クチンプローブによるウェスタンブロットで陽性シグナルを与 えたが (Hirabayashi et al., 1996)、ラクトースを添加しても、リ ガンド糖タンパク質との結合は完全に阻害されなかったことは 注目される。なぜなら、ラミニンに対する結合は、同じ濃度の ラクトースで完全に阻害されたからである。したがって、線虫 $16 \mathrm{kDa}$ ガレクチンが認識する内在性リガンド糖鎖は、脊椎動物 ガレクチンの相手糖鎖とはやや異なるものなのかもしれない。

D. ゲノムプロジェクトが予測した他のC. elegansガレクチン群 C. elegans ゲノムプロジェクト (Coulson et al., 1992) は、約 $10^{8}$ 塩基対からなる C. elegans 遺伝子の完全解読を目指し現在進 行中である。第三染色体から始まり (C. elegans ゲノムは 5 本の 常染色体と 1 本の性染色体からなる)、現在、全配列の約 $60 \%$ を 決定しているという。その過程で、驚くべき数のガレクチン関 連遺伝子の存在が明らかになってきた (originally based on personal communication with D.N.W. Cooper ; 表 I)。プロジェクトで は、以下のようなストラテジーでゲノム解析を系統的に行う。先 ず、Genefinder (P. Green and L. Hillier, unpublished) というプロ グラムを使い、読み枠の検索とエキソン・イントロンのスプラ イシング箇所の予測をする。次に、いくつかの Blastプログラム (Altschul et al., 1990) を用いて、既知の遺伝子、アミノ酸配列と のホモロジー検索を行う。このようにして解析された情報は GeneBank/EMBL/DDBJ のDNAのデータベースにも付加される。

現在まで、6つのガレクチン関連遺伝子が同定されている。 そのうちの 4 つは直列反復型のガレクチン分子をコードしてい る(ここでは先の $32 \mathrm{kDa}$ ガレクチンを Cel-I とし、これら新し いメンバーをCel-II、III、IV、Vとする)。予測されたアミノ酸配 列は、 $32 \mathrm{kDa}$ ガレクチン (Cel-I) と 40〜75\%一致していた。RT-

Table I. So far identified galectin-related genes.

\begin{tabular}{|c|c|c|c|c|c|c|c|}
\hline \multirow[t]{2}{*}{ Desig. } & \multirow[t]{2}{*}{ Cosmid (Acc. No) } & \multirow[t]{2}{*}{ Chrom } & \multirow{2}{*}{$\begin{array}{l}\text { Expression } \\
\text { (cDNA) }\end{array}$} & \multirow{2}{*}{$\begin{array}{l}\text { AA } \\
\text { Residues }\end{array}$} & \multirow{2}{*}{$\begin{array}{l}\text { Binding } \\
\text { to ASF }\end{array}$} & \multicolumn{2}{|c|}{ \% Identity to N32 } \\
\hline & & & & & & repeat $-\mathrm{i}$ & -ii \\
\hline \multicolumn{8}{|c|}{ \#Tandem-repeat type } \\
\hline Cel-I $\left(\mathrm{N} 32^{*}\right)$ & No & II & Yes & 279 & Yes & 100 & 100 \\
\hline Cel-II & F52H3.7 (Z66512) & II & Yes & 280 & Yes & 74 & 67 \\
\hline Cel-III & ZK892.1 (Z48638) & II & Yes & 289 & Yes & 70 & 73 \\
\hline Cel-IV & C44F1.3 (Z48067) & III & Yes & 283 & $?$ & 45 & 43 \\
\hline Cel-V & ZK1248.16 (U29244) & II & Yes & 333 & $?$ & 36 & 43 \\
\hline \multicolumn{8}{|l|}{ \#Proto type } \\
\hline Cel-VI No (N16**) & No & $?$ & Yes & 146 & Yes & 28 & 27 \\
\hline \multicolumn{8}{|c|}{ \#Modified proto type } \\
\hline Cel-VII & R07B1.2 (Z48621) & $\mathrm{X}$ & Yes & 182 & ? & 32 & 27 \\
\hline Cel-VIII & R07B1.10 (Z48621) & $\mathrm{X}$ & $?$ & 184 & ? & 26 & 27 \\
\hline
\end{tabular}

* 32-kDa galectin : Hirabayashi, J. Satoh, M., and Kasai, K. (1992) J. Biol. Chem. 267, 15485-15490

** 16-kDa galectin : Hirabayashi, J. Ubukata, T., and Kasai, K. (1996) J. Biol. Chem. 271, 2497-2505 
According to RT-PCR analysis, all of these genes are actually expressed to various extents. Interestingly, Cel-II (cosmid F52H3) and -III (ZK892) are highly homologous to each other, as well as the Cel-I (ca. 70\% identities to one another), and all of them have been mapped to the same chromosome II (Table I). In addition, among them, the conserved hexapeptide "HisPhe-Asn-Pro-Arg-Phe" is replaced with "His-Val-Ser-ValArg-Phe" in the N-terminal domains of both Cel-I and Cel-II, and with "His-Leu-Ser-Ile-Arg-Phe" in that domain of Cel-III. These observations suggest that Cel-I, -II and -III have diverged at a relatively late stage of evolution, and thus, have retained similar properties. We cloned the full-length cDNAs of Cel-II and -III and expressed their protein product as a fusion protein in a conventional bacterial system. Both recombinant proteins formed a precipitate (inclusion body) upon bacterial expression, and required $8 \mathrm{M}$ urea for complete solubilization as in the case of Cel-I (Arata et al., in press). As a result, both Cel-II and -III proved to bind to asialofetuin-agarose (Hirabayashi and Kasai, unpublished result).

On the other hand, homologies to the other two tandemrepeat-type galectins (Cel-IV and -V) are much lower (ca. $40 \%$ ). Since we have not confirmed cDNA sequences for them, there still remains possibility that predicted exon/intron boundaries are incorrect, which would greatly alter the resulting amino acid sequences. Predicted polypeptides of the remaining two genes (Cel-VII and -VIII) are more unusual, because they are not included in any of the known structural types. They show high sequence similarity to each other ( $43 \%$ identity at the predicted amino acid level), and have somehow a redundant C-terminal tail, which makes them about 40 amino acids longer than the $16-\mathrm{kDa}$ galectin $(\mathrm{Cel}-\mathrm{VI})$. Nevertheless, it is possible to assign them to the modified proto type.

If mRNA (cDNA) transcripts from the above candidate genes can be detected, the genes are actually expressed. However, this does not necessarily mean that the thus expressed gene products are really functional as galectins; i.e., it is not certain whether they have galactose-binding activity or not. To the present, however, all five of the identified tandem-repeattype galectins have been proved to be actually expressed, and at least three of them (Cel-I, II, and -III) have been found to be functional. It is not known whether the two modified proto-type galectins (Cel-VII and -VIII) are really expressed as the predicted polypeptides or not. Our preliminary RT-PCR analysis detected the presence of Cel-VII mRNA, but it rather showed the presence of splicing varients. Apparently, systematic functional studies on this increasing number of candidate galectin genes are necessary.

\section{E. Merits of Studies with C. elegans}

The number of possible galectin genes is still increasing as a result of updating of the genome project. In consideration
PCR 解析を行うと、これらの遺伝子は程度こそ異なるがいずれ も実際に発現していた。興味深いことに、Cel-I (32 kDa ガレク チン)、Cel-II (コスミドクローン F52H3)、Cel-III (ZK892) の 3 者は、互いによく似て扔り(アミノ酸配列上、約 70\%一致)、す べて第二染色体に位置していた (表 1)。これに加え、保存性の 高いへキサペプチド "His-Phe-Asn-Pro-Arg-Phe"がこれら 3 者の $\mathrm{C}$-端側ドメインでは保存されているのに対し、N-端側ドメイン ではどれも変異が見られた。すなわち、Cel-I と Cel-IIでは "HisVal-Ser-Val-Arg-Phe"に置換しており、Cel-IIIでは"His-Leu-SerIle-Arg-Phe" となっている。このことから、Cel-I、II、III が分子 進化の比較的遅い時点で分岐し、その結果、現在まで類似の性 質が維持されてきたと考えられる。我々は、これらに対する全 長 cDNAを単離し、融合タンパク質の形で大腸菌発現を試みて いる。Cel-II、III 両組み換えタンパク質は、発現に際し Cel-I と 同様 (Arata et al., in press)、沈澱 (封入体) を形成し、菌体から の可溶化には $8 \mathrm{M}$ 尿素が必要であった。しかし、結局、Cel-II、 Cel -III 双方にアシアロフェツイン - アガロースに対する結合活 性が確認された (Hirabayashi and Kasai, unpublished result)。

一方、他の $2 つ の$ 直列反復型ガレクチン (Cel-IV および-V) の Cel-I に対するホモロジーは比較的低い (約 40\%一致)。我々 はこれらに対する全長CDNAの配列をまだ確認していないので、 プログラムの予測通りにイントロンのスプライシングが起こっ ているかどうかはまだ不確かである。そうした場合には読み枠 がずれることもありうる。残る2つの遺伝子 (Cel-VII、㧍よび、 VIII)の構造はある意味では異常である。つまり、これらから予 想されるタンパク質構造は、既知のいずれの構造タイプとも違つ ているからである。これらは、予測された限りでは、相互の間 での類似性が最も高く(アミノ酸レベルで $43 \%$ 一致)、双方とも やや長めのC-末端尾部を持つ (先の $16 \mathrm{kDa}$ ガレクチン (Cel-VI) より約 40 アミノ酸長い)。しかし、これらを一種の“変形”とし てプロト型に分類しておくことは可能であろう。

もし、これら一連のガレクチン関連遺伝子に対する mRNA (cDNA)が検出されれば、その遺伝子は発現していることを意味 するが、必ずしもガレクチンとしての機能を発揮しているとは 限らない。ガラクトース結合活性を持っているかどうかは別の 問題である。しかし、我々はすでに、上記 5 つの直列反復型ガ レクチン遺伝子が実際に発現されていることを確認しており、少 なくともそのうち3つ (Cel-I、II および-III) はガレクチンとし ての機能をもっていた(ガラクトース結合活性を持つ)。一方、変 形プロト型ガレクチンであるCel-VIIとVIIIが本当に予測通りの 配列で発現されているかはまだ定かではない。予備的なRT-PCR 解析ではCel-VIIのmRNAは検出されているが、これにはいくつ かのスプライシングバリアントが存在するらしい。このように、 ゲノムプロジェクトが予測したガレクチン候補遺伝子であるが、 今後、これらの機能解析に関する研究がますます重要になって くるだろう。

E. C. elegans研究における利点

ゲノムプロジェクトの進展によって、今後ガレクチン候補 遺伝子が大増殖する可能性は高い。C. elegansのゲノムサイズが 
of the a relatively small genome size of C. elegans ( $\left.1 \times 10^{8} \mathrm{bp}\right)$, this finding is almost astonishing. In this context, with no exaggeration, C. elegans is the sole multicellular animal of which the complete genome sequence will be available in very near future. Once the gene of interest is cloned, its expression pattern can be readily analyzed by a convenient procedure using green fluorescent protein (GFP) as a reporter gene at each developmental stage of living worms without fixation. For elucidation of unknown gene function, the recently developed "gene knock-out" technology is extremely powerful, even though it often meets difficulty in evaluation of the results due to redundancy. In C. elegans, a procedure utilizing insertion of the transposone "Tc1" is commonly used for this purpose instead of homologous recombination, partly because the introduced recombination is not fully stable in C. elegans, and also because a useful Tc1-insertion mutant library (Zwaal et al., 1993) is now available. Tc1-transposed target gene, the function of which is usually destroyed, can be screened systematically by PCR using a gene-specific primer and Tc1-specific primer to detect the transposone insertion. Further, by mating two independent mutants, double or triple gene-targetted nematodes can also be obtained.

Other than genetic approaches in the nematode, various other approaches are necessary to elucidate galectin function(s); e.g., identification of endogenous glycoconjugate ligands, elucidation of cross-linking features and effects on signal transduction pathways. In this context, conventional biochemistry including glycobiology has less advanced in $C$. elegans than genetics, anatomy, and developmental and neurobiology.

\section{F. Perspectives}

Though galectins have been found in wide animal species including vertebrates, nematodes, and sponges, do all metazoan species have galectin as a house-hold protein? However, in our preliminary screening of various invertebrates, e.g., fly, shrimp, earthworm, turbo, sea anemone, etc., we have not been able to find any galectin-related protein. Then, does this result means that galectins are expressed only in specific phyla (vertebrates, nematodes and sponges)? Our answer is emphatically "No!"

Under the concept of "bricolage" (Jacob, 1982; Hirabayashi, 1993), all living organisms make a number of gene copies (duplications) in various forms over a geological time span: "parallel-type" gene duplications result in the formation of a multiple gene family, while some of their descendants may be subjected to "tandem-type" gene duplication. Such tandemly repeated structures are considered to be useful for increasing avidity and/or specificity, and, in fact, are common in a number of binding proteins; e.g., mannose receptor of the C-type lectin family, wheat germ agglutinin, ricin, legume
$10^{8}$ 塩基対と比較的小さい (ヒトの約 1/30) ことを考えると、今 回得られた知見は驚嘆に值する。C. elegansは、きわめて近い将 来に遺伝情報が完全解読されてしまう唯一のモデル動物である が、遺伝子の機能解析に関してもいろいろな利点がある。一度 目的の遺伝子がクローン化されれば、その発現パターンはグリー ンフルオレッセントプロテイン(GFP) をレポーター遺伝子とし た簡便法ですぐに調べることができる。各発生段階の虫を固定 化せずに解析できるメリットは大きい。機能のよくわからない 遺伝子の役割を調べる際に、遺伝子を「ノックアウト」する方 法は有用である。この場合にも、類似遺伝子などの存在によっ て (いわゆる redundancyの問題)、結果の解釈がしばしば困難に なるが、このアプローチが遺伝子機能の解析に強力であること には変わらない。C. elegansの場合には「相同的組み換え法」の 代わりに、Tc1”というトランスポゾンを利用した方法が一般に 用いられる。C. elegansでは導入された組み換えが十分安定では ないことと、ランダムにTc1 挿入の起こった便利な変異体 (mut2) のライブラリーがすでに揃っているからである (Zwaal et al., 1993)。Tc1トランスポゾンが標的遺伝子に挿入されると一般に 遺伝子は機能破壊されるが、この変異を含む虫は遺伝子特異的 プライマーと Tc1 特異的プライマーを用いる系統的 PCR でスク リーニングすることができる。さらに、別の遺伝子に変異が入っ た虫同士を掛け合わせることによって、二重、三重の変異体を 調製することも十分可能である。

しかし、線虫 C. elegans を用いたガレクチンの機能解析に は、こういった遺伝学的な解析だけでなく、他の様々な角度か らのアプローチが求められる。「内在性の複合糖鎖リガンドを突 き止めること」、「架橋形成の実体を解き明かすこと」、そして 「その結果がいかにしてシグナル伝達へとつながるのか等を解 析していくことが必要だろう。この意味では、線虫では糖鎖生 物学を含む従来の生化学的な研究が、遺伝学、発生学、神経生 物学と比べてあまり進んではいないのが残念なことである。

\section{F. 展 望}

ガレクチンは脊椎動物、線虫、海綿をはじめとする多くの 動物で見出されているが、果たして後生動物のすべてが「ハウ スホールドタンパク質」としてのガレクチンをもっているのだ ろうか。我々が予備的に様々な無脊椎動物 (八エ、エビ、ミミ ズ、サザエ、イソギンチャクなど) をスクリーニングしたとこ ろ、ガレクチンと思われるタンパク質は見つからなかった。で は、ガレクチンは、脊椎動物、線虫、海綿といった、いわば特 殊な動物門でしか発現されていないのだろうか。我々の答えは 断じて「否」である。

「ブリコラージュ」の概念によれば、すべての生物は地質学 的な時間をかけて幾つもの遺伝子のコピーを作り、それを様々 な用途に「使い回し」している (Jacob, 1982；Hirabayashi, 1993)。 重複の仕方はいくつかあるが、もし「パラレル」に起これば子 孫遺伝子が増え多重な遺伝子家系ができるだろう。一方、遺伝 子数を増やさず「タンデム」に遺伝子重複が起これば、直列反 復型のタンパク質が生成する。ところで、このような繰り返し 構造をつくることは、生命にとって結合力や特異性を増す目的 には手っとり早い方法ではないだろうか。事実、こういった繰 り返し構造は結合性タンパク質一般に多く見られる。C型レク 
protease inhibitors, plasminogen kringle structures, immunoglobulins, etc. In consideration of the fact that both nematodes and mammals make maximal use of tandem-repeat-type galectins, covalently linked CRDs appear to have significant advantage for some fundamental biological reason, e.g., maintenance of both multivalency and heterobifunctionality.

Since the tandem-repeat-type nematode galectins so far identified, except for Cel-I, do not seem to be easily solubilized with readily available saccharides such as lactose, the absence of literature on invertebrate galectins may be attributed to the difficulty in extraction of these tandem-repeat binding proteins. To support this idea, we recently detected a possible 32-kDa galectin homologue in the parasitic nematode Ascaris. This $32-\mathrm{kDa}$ protein was only slightly detected in the lactose extract, but was found to be significantly abundant in the Triton-X extract after lactose extraction (Hirabayashi and Kasai, unpublished result). This detergent fraction includes various glycosylated membrane proteins. This observation clearly indicates that the Ascaris $32-\mathrm{kDa}$ galectin is only partially extractable with lactose, possibly by forming a rather stable (or insoluble) complex with glycoconjugate ligands.

As described, studies on invertebrate galectins have opened a new area represented by the finding of "tandem-repeat-type" galectins in a useful model animal, C. elegans. Hopefully, future systematic functional analyses of all of the discovered galectin genes along with a profit of the ongoing genome project will lead to our understanding of the fundamental biology of galectins.

\section{Acknowledgements}

We thank Dr. D.N.W. Cooper for kindly informing the result of EST analyses of C. elegans. This work was supported by grant-in-aid for scientific research (5274101, 07857168, 08772109) from the Ministry of Education, Science and Culture of Japan, and by grants from the Mitsubishi Foundation, Naito Foundation, and Kihara Memorial Yokohama Foundation.

Received on November15, 1996, accepted on December 4,1996
チン家系に属するマンノース受容体、コムギ胚芽凝集素、植物 毒素リシン、豆科プロテアーゼ阻害剂、プラスミノーゲン・ク リングル構造、免疫グロブリン、等々その例は多い。線虫や哺 乳類の例から明らかなように、直列反復型のガレクチンは最も

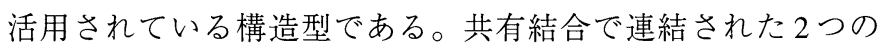
CRDからなる構造は、多価という性質を安定に保ったり、等価 でない結合特異性を発揮するなど、有利な点をもっているにち がいない。

これまで遺伝子として同定されている直列反復型の線虫ガ レクチンは、32 kDa ガレクチンを除き、ラクトースの様な簡単 な糖では容易に可溶化されないから、無脊椎動物ガレクチンの 記載が文献上ないのは、本構造をもったガレクチンの「抽出さ れにくさ」による可能性がある。この考えを支持する知見とし て、最近我々が精製を試みた寄生性線虫、回虫 (Ascaris) のガ レクチンについて述べよう。C. elegans $32 \mathrm{kDa}$ ガレクチンに対 する抗体で同じ分子量をもったタンパク質がウェスタンブロッ トで検出されたが、このタンパク質はラクトース抽出物にはわ ずかしか検出されず、その後不溶性画分を Triton-Xで可溶化し た膜画分に豊富に認められた (Hirabayashi and Kasai, unpublished result)。この膜画分にはガレクチンのリガンドである糖タンパク 質が多く含まれているはずであるから、Ascarisにおける $32 \mathrm{kDa}$ ガレクチンの相同物は、複合糖鎖リガンドと安定な(あるいは不 溶性の)複合体を形成し、ラクトースでは容易に抽出されないと 考えられる。

無脊椎動物ガレクチンの研究は、モデル動物 C. elegansに おける直列反復型ガレクチンの発見に代表されるように、新し い研究の舞台をととのえた。ゲノムプロジェクトで見い出され る多くのガレクチン関連遺伝子を系統的に機能解析していくこ とで、ガレクチンの生物機能に関する我々の理解が深まること を期待したい。 


\section{Profile of the Author}

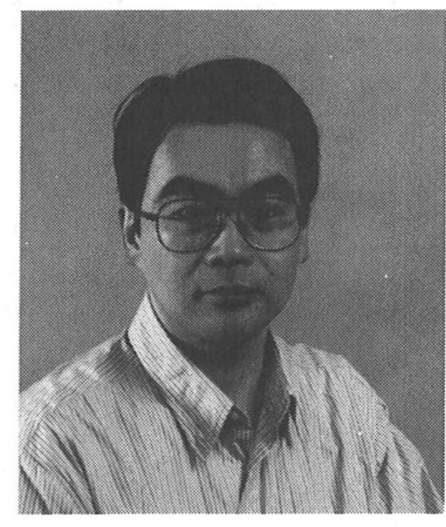

Jun Hirabayashi

Graduated from

Tohoku University in 1982 (MS), received his Ph.D in Chemistry (Faculty of Science, Tohoku University) in 1989. The thesis is entitled, "Isolation, Characterization and Structures of $14 \mathrm{~K}$-type

Soluble $\beta$-Galactoside-binding Lectins of Chick and Human". He started his professional career from 1982 as an Assistant Professor in the Department of Biological Chemistry, Faculty of Pharmaceutical Sciences, Teikyo University, and is presently a Lecturer in the same laboratory.

Main theme: as a protein chemist, he has long been involved in purification and molecular characterization of diverse carbohydrate-binding proteins including galectins. His approach to structure-function studies is almost orthodox but also has insight into comparative biochemical and evolutionary aspects. His main interest is to clarify "how and why carbohydrate-binding proteins have evolved". On this point, his original idea "On the Origin of Elementary Hexoses" is described in a recent Quart. Rev. Biol. issue (71, 365-380, 1996); where he insists that fructose-glucose-mannose should have been the "first triplet" saccharides by a simple chemical reason, and thus, dominated the most fundamental niche in nature, while galactose was a "latecomer", but has been widely utilized as a "recognition saccharide" in particular multicellular organisms, being expressed at a non-reducing terminal and carrying a distinguishable axial 4-OH group.

$\mathrm{He}$ is also an investigator of "slalom chromatography" in the analytical field of high-performance liquid chromatography (a novel size-fractionation phenomenon based on a hydrodynamic principle, specifically observed for large DNA).

He has been an Associate Editor of TIGG from 1993, and also taken a role of an Associate Secretory (Auditor) of FCCA from 1996. Creation of this "Recent Topics on Galectins", is his first monumental work as an Editor. 